"At a meeting of the Anatomical and Physiological Society of Edinburgh, in 1836, Knox referred to the Archives Génerales of that year, containing an analysis of various German monographs on the structure and physiology of the eyeball, and the confirmation of his views on the Annulus albus by Arnold."

As is well known, Knox was the anatomist who received most of the bodies of the victims of Burke and Hare; after 1830, his career as a great teacher was practically over; and perhaps the odium attaching to his name on account of his association with the West Port murders may have led men to overlook his research work and its results.

\title{
XIII INTERNATIONAL OPHTHALMOLOGICAL CONGRESS, HOLLAND, September 5-13, 1929.
}

\section{Subscribers to International Ophthalmological Council Fund}

\section{FIFTH LIST}

Societies, Institutions, etc.

Bulgarian Ophthalmological Society. Society of Oculists of West Poland.

INDIVIDUALS.

$\begin{array}{ll}\text { Marquez, M. } & \text { Vail, Derrick T., Jr. } \\ \text { Preziosi, L. } & \text { Weed, Harry M. }\end{array}$

We desire to remind any ophthalmologists who intend to go to Amsterdam for the Congress and who have not yet sent their subscriptions that it will greatly facilitate the work of the National Committee if they will do so at once. Seven hundred members have already been enrolled and 232 communications covering all branches of Ophthalmology have been promised. Even if any reader is unable to attend the meetings he will find it almost essential to possess himself of a copy of the Transactions, which promise to form a compendium of recent work in Ophthalmology. So that even those who do not see their way to go to Holland should, at least, become members so that they may be supplied with a copy of the Transactions when they appear.

Subscriptions (25 Dutch florins $=£ 22 \mathrm{~s}$. English money) should be sent to

Dr. H. M. Roelofsz,

Director of the Incassobank,

Heerengracht 531,

Amsterdam. 